\title{
Underweight and overweight/obesity among adults in Afghanistan: prevalence and correlates from a national survey in 2018
}

Supa Pengpid ${ }^{1,2}$ and Karl Peltzer ${ }^{3,4^{*}}$ (D)

\begin{abstract}
Background: The study aimed to estimate the prevalence and correlates of underweight and overweight/obesity among adults in Afghanistan.

Methods: National cross-sectional survey data of 3779 persons aged 18-69years were analysed. Multinomial logistic regression was used to estimate factors associated with underweight and overweight/obesity relative to normal weight.

Results: In all, $7.8 \%$ of the study sample was underweight $\left(\mathrm{BMl}<18.5 \mathrm{~kg} / \mathrm{m}^{2}\right), 49.5 \%$ had normal weight (BMI 18.5-24.9 $\left.\mathrm{kg} / \mathrm{m}^{2}\right), 25.5 \%$ overweight $\left(25.0-29.9 \mathrm{~kg} / \mathrm{m}^{2}\right)$, and $17.2 \%$ obesity. In adjusted multinomial logistic regression, factors negatively associated with underweight were male sex (adjusted relative risk ratio (ARRR): 0.30, 95\% confidence interval (CI): 0.15-0.58) and hypertension (ARRR: $0.51,95 \% \mathrm{Cl}: 0.27-0.95$ ) and factors positively associated with underweight were sedentary behaviour (ARRR: 1.85, 95\% Cl: 1.11-3.10) and current tobacco use (ARRR: 2.58, 95\% Cl: 1.08-6.16). Factors positively associated with overweight/obesity were aged 30-44 years (ARRR: 2.00, Cl: 1.51-2.66) and aged 45-69 years (ARRR: 1.58, Cl: 1.09-2.31) (compared to 18-29years) (ARRR: 1.28, Cl: 1.14-2.18), hypertension (ARRR: 2.74, Cl: 1.89-3.96), and type 2 diabetes (ARRR: 1.82, Cl: 1.13-2.94), and high physical activity (ARRR: 0.70, Cl: 0.50-0.98) was negatively associated with overweight/obesity.
\end{abstract}

Conclusion: Almost one in ten adult respondents were underweight and more than two in five were overweight/obese, confirming a dual burden of malnutrition in Afghanistan.

Keywords: Body weight, Health behaviour, Health status, Adulthood

\section{Introduction}

Worldwide, among adults, the prevalence of undernutrition $\left(18.5<\mathrm{kg} / \mathrm{m}^{2}\right)$ was $8.8 \%$ among men and $9.7 \%$ among women, and the prevalence of obesity (BMI $\geq 30$ $\mathrm{kg} / \mathrm{m}^{2}$ ) was $10.8 \%$ among men and $14.9 \%$ among women [1]. In the Eastern Mediterranean region, among adults,

\footnotetext{
* Correspondence: kfpeltzer@gmail.com

${ }^{3}$ Department of Psychology, University of the Free State, Bloemfontein, South Africa

${ }^{4}$ Department of Psychology, College of Medical and Health Science, Asia University, Taichung, Taiwan

Full list of author information is available at the end of the article
}

a high average prevalence of overweight/obesity (51\%) [2], ranging from 25 to $81.9 \%$ has been reported [3]. In Iran, the prevalence of underweight was $5.9 \%$ and $49.9 \%$ had overweight/obesity (15-65 years, in 2004-2005) [4]; in Iraq ( $\geq 15$ years, in 2015), underweight was $3.6 \%$ and overweight/obesity $65.7 \%$ [5]; in Jordan, overweight or obesity (BMI $\geq 25 \mathrm{~kg} / \mathrm{m}^{2}$ ) was $77.2 \%$ among men and $74.5 \%$ among women ( $\geq 18$ years; 2017) [6]; in Morocco, underweight was $5.6 \%$ and overweight/obesity $56.1 \%$ ( $\geq$ 18 years; 2017) [7]; and in Palestine (18-64 years, 1999-

C C The Author(s). 2021 Open Access This article is licensed under a Creative Commons Attribution 4.0 International License, which permits use, sharing, adaptation, distribution and reproduction in any medium or format, as long as you give appropriate credit to the original author(s) and the source, provide a link to the Creative Commons licence, and indicate if changes were made. The images or other third party material in this article are included in the article's Creative Commons licence, unless indicated otherwise in a credit line to the material. If material is not included in the article's Creative Commons licence and your intended use is not permitted by statutory regulation or exceeds the permitted use, you will need to obtain permission directly from the copyright holder. To view a copy of this licence, visit http://creativecommons.org/licenses/by/4.0/ The Creative Commons Public Domain Dedication waiver (http://creativecommons.org/publicdomain/zero/1.0/) applies to the data made available in this article, unless otherwise stated in a credit line to the data. 
2000), underweight was $1.5 \%$ and overweight/obesity $62.4 \%[8]$.

To our knowledge, there are no national adult body weight status data for Afghanistan. Afghanistan is a lowincome country, its living standards are among the lowest in the world, it has a population of 36.6 million, life expectancy at birth was 52.8 years, and the adult literacy rate was $43 \%$ (55.5\% among men and $29.8 \%$ among women) [9].

In local community surveys in urban centres in Afghanistan, the following proportions of body weight status have previously been shown: in Kabul City ( $\geq 40$ years, in 2011-2012), underweight $1.1 \%$ and overweight/ obesity 69.3\% [10]; in Kabul (25-70 years, in 2015), $57.6 \%$ overweight/obesity [11]; in Jalalabad (25-65 years, in 2013) underweight 6.1\% [12] and overweight/obesity $57.4 \%$ [13]; and in Kabul, Balkh, Hirat, Nangarhar, and Kandahar (25-70 years, during 2013-2015), overweight/ obesity was $52.7 \%$ [14]. In a national study among women 15-49 years in Afghanistan, the prevalence of underweight was $8.6 \%$ [15].

Both undernutrition and overnutrition in adulthood have been linked to various negative health effects, including morbidity and mortality [16, 17]. As reviewed [18], sociodemographic factors associated with adult underweight may include female sex, younger and older age, lower socioeconomic status, and residing in rural areas. Health variables associated with adult underweight may include poor diets, smoking, and not having chronic conditions. As reviewed [18], sociodemographic factors associated with overweight/obesity include female sex, increasing age, higher socioeconomic status, and urban residence, and health variables associated with overweight/obesity may include poor diet, physical inactivity, not smoking, diabetes, and hypertension. Afghanistan has a high prevalence of undernutrition in children $(19.1 \%$ in 2018) under the age of five $[9,15]$, which may affect adult weight status. The study aimed to estimate for the first time the national prevalence and correlates of underweight and overweight/among adults in Afghanistan.

\section{Methods}

This is a secondary analysis conducted using nationally representative population-based and cross-sectional data from the "2018 Afghanistan STEPS survey" [19]. The 2018 Afghanistan STEPS survey data and more detailed sampling methods can be accessed [20]. Briefly, a multistage cluster sampling was used to generate a nationally representative sample of adults aged 18-69 years. Stage 1 or primary sampling units were 55 districts, followed by villages or blocks (secondary sampling units) and households (tertiary sampling units). One person from each household was randomly selected [20]. In total,
3956 persons aged 18-69 years were potentially eligible in this study. However, 177 women were excluded as they had indicated to be pregnant during the study so that 3779 participants were included in the final data analysis. The study instrument was translated to Pashto and Dari and piloted [20]. The study was approved by the Ministry of Public Health Ethics Board, and written informed consent was obtained from participants [20].

\section{Measures}

Anthropometric measurements were taken by trained healthcare staff in a safe and secure area; height and weight were measured using a portable electronic weighing scale and measuring inflexible bars [20]. "Height in centimetres is measured at the exact point to the nearest $\mathrm{mm}$. Participants were weighed to the nearest $0.01 \mathrm{~kg}$, in their light clothes, on a load-cell-operated digital scale. The scale used during the survey were first calibrated to a standard weight and checked daily." [20]. Body mass index (BMI) was classified as " $<18.5 \mathrm{~kg} / \mathrm{m}^{2}$ underweight, $18.5-24.4 \mathrm{~kg} / \mathrm{m}^{2}$ normal weight, $25-29.9 \mathrm{~kg} / \mathrm{m}^{2}$ overweight, and $\geq 30 \mathrm{~kg} / \mathrm{m}^{2}$ obesity" [21].

Hypertension or raised blood pressure (BP) was defined as "systolic BP $\geq 140 \mathrm{~mm} \mathrm{Hg}$ and/or diastolic BP $\geq 90$ $\mathrm{mmHg}$ or where the participant is currently on antihypertensive medication." [22]. BP was measured with a calibrated sphygmomanometer after participants had been seated at least for $15 \mathrm{~min}$, and three minutes in between readings. Of the three BP measurements, the last two readings were averaged [20].

Diabetes was defined as "fasting plasma glucose levels $\geq 7.0 \mathrm{mmol} / \mathrm{L}(126 \mathrm{mg} / \mathrm{dl})$; or using insulin or oral hypoglycaemic drugs; or having a history of diagnosis of diabetes" [23].

Health risk behaviour variables comprised alcohol use, tobacco use status, sedentary behaviour ( $\geq 8 \mathrm{~h}$ /day [24]), and "low, moderate or high physical activity based on the Global Physical Activity Questionnaire" [25].

Dietary behaviour included "daily fruit and vegetable consumption measured from the total number of servings of fruit and vegetables eaten per day in a typical week." Meals outside the home were assessed with the question, "On average, how many meals per week do you eat that were not prepared at home? By meal, I mean breakfast, lunch and dinner?" (Number) [20]. Adding salt to meals was measured with the item "How often do you add salt or a salty sauce such as soya sauce to your food right before you eat it or as you are eating it?" (Response options ranged from $1=$ always to $5=$ never). Eating processed food was assessed with the item "How often do you eat processed food high in salt? By processed food high in salt, I mean foods that have been altered from their natural state, such as packaged salty snacks, canned salty food including pickles and 
preserves, salty food prepared at a fast food restaurant, cheese, bacon and processed meat." (Response options ranged from $1=$ always to $5=$ never). "What type of oil or fat is most often used for meal preparation in your household?" Responses were grouped into mainly butter or ghee $(59.5 \%)$ (or lard or suet $0.3 \%$, margarine $0.3 \%$, none in particular $1.7 \%$ or none $0.0 \%$ ) used $=0$ and vegetable oil $(38.2 \%)=1[20]$.

Sociodemographic information included age, sex, highest educational level, number of adult household members, and residence status [20]. Household crowding has been found to have an inverse relationship with socioeconomic status [26].

\section{Data analysis}

All statistical procedures were adjusted for complex sample design and conducted with "STATA software version 13.0 (Stata Corporation, College Station, TX, USA)". The data were weighted "to make the sample representative of the target population in Afghanistan (by sex and by age group: 18-29, 30-44, 45 and over)." [20]. Chi-square test calculated differences in proportions. Multivariable multinomial logistic regression was used to estimate predictors of underweight and overweight/obesity (with normal body weight forming the reference category). Covariates were included based on a previous review of literature [18]. No multi-collinearity was detected. Missing data were excluded from the analysis. $P<0.05$ was considered significant.

\section{Results}

\section{Sample and body mass index information}

The sample consisted 3779 individuals aged 18-69 years (median age: 35 years, 24-48 interquartile range), and $55.9 \%$ were male. Two in five participants $(41.8 \%)$ were living with six or more adult household members, 59.0\% had no formal education, and $42.4 \%$ lived in rural areas. In all, $7.8 \%$ of the study sample was underweight (BMI $<18.5 \mathrm{~kg} / \mathrm{m}^{2}$ ), $49.5 \%$ had normal weight (BMI 18.5-24.9 $\left.\mathrm{kg} / \mathrm{m}^{2}\right), 25.5 \%$ overweight $\left(25.0-29.9 \mathrm{~kg} / \mathrm{m}^{2}\right)$, and $17.2 \%$ obesity. Further sample details are shown in Table 1.

\section{Multinomial logistic regression for underweight and overweight/obesity}

In adjusted multinomial logistic regression, factors negatively associated with underweight were male sex (adjusted relative risk ratio (ARRR): $0.30,95 \%$ confidence interval (CI): 0.15-0.58) and hypertension (ARRR: 0.51, 95\% CI: 0.27-0.95), and factors positively associated with underweight were sedentary behaviour (ARRR: 1.85, 95\% CI: 1.11-3.10) and current tobacco use (ARRR: 2.58, 95\% CI: 1.08-6.16). Factors positively associated with overweight/obesity were aged 30-44 years (ARRR: 2.00, CI: 1.51-2.66) and aged 45-69 years (ARRR: 1.58, CI: $1.09-$
2.31) (compared to 18-29 years) (ARRR: 1.28, CI: 1.142.18), hypertension (ARRR: 2.74, CI: 1.89-3.96), and type 2 diabetes (ARRR: 1.82, CI: 1.13-2.94), and high physical activity (ARRR: 0.70, CI: 0.50-0.98) was negatively associated with overweight/obesity (see Table 2).

\section{Discussion}

In this national 2018 Afghanistan STEPS survey, the prevalence of underweight (7.8\%) was higher than in Kabul City $(1.1 \%, \geq 40$ years, 2011-2012) [10], in Jalalabad $(6.1 \%, 25-65$ years, in 2013) [12], in Iran $(5.9 \%, 15-$ 65 years, 2004-2005) [4], in Iraq (3.6\%, $\geq 15$ years, 2015) [5], in Morocco (5.6\%, $\geq 18$ years, 2017) [7], and Palestine (1.5\%, 18-64 years, 1999-2000) [8], but similar to a national study among women in Afghanistan (8.6\%, $15-49$ years vs. 9.1\%, 18-69 years, in this study) [15], and the global prevalence of underweight $(8.8 \%$ among men and 9.7\% among women) [1]. The found prevalence of overweight/obesity $\left(42.7 \%, \geq 25.0 \mathrm{~kg} / \mathrm{m}^{2}\right)$ in this study is lower than the prevalence rates found in urban centres in Afghanistan, e.g., in Kabul City $(69.3 \%$, $\geq 40$ years, 2011-2012) [10], in Kabul (57.6\%, 25-70 years, 2015) [11], in Jalalabad (57.4\%, 25-65 years, 2013) [13], in Kabul, Balkh, Hirat, Nangarhar, and Kandahar (52.7\%, 25-70 years, 2013-2015) [14], in Iran $(59.3 \%, 2016)$ [27], in Iraq $(65.7 \%, \geq 15$ years, in 2015) [5], in Morocco $(56.1 \% \geq 18$ years, 2017) [7], Palestine $(62.4 \%, 18-64$ years, 1999-2000) [8], and in Jordan $(>75 \%, \geq 18$ years, 2017) [6].

Findings show the double burden of undernutrition $(7.8 \%)$ and overnutrition $\left(42.7 \%, \geq 25 \mathrm{~kg} / \mathrm{m}^{2}\right)$ in the lowincome country, Afghanistan. The co-existence of undernutrition (15.6\%) and overnutrition (18.0\%) has also been found in low-income countries in the Asia Pacific region [28]. The trend in the reduction of underweight and increase of overweight/obesity $[1,28]$ seems to have been confirmed in this study in Afghanistan. "Rapid dietary and lifestyle transition is the leading direction of dual burden with overnutrition increase and diet-related noncommunicable diseases (NCDs)" [28, 29]. In addition, it is possible that the high prevalence of undernutrition in children under the age of five in Afghanistan [15] has led to increased overnutrition in adulthood [30]. Increased efforts on policy initiatives and lifestyle changes are needed in Afghanistan to combat the double malnutrition burden.

The prevalence of underweight was the highest among 18 to 29 year olds (8.9\%) and among women $(9.1 \%)$, which was also found in previous studies [31-33], and may be attributed to food insecurity, in particular among young women [15, 34]. Akseer et al. [15] showed that younger adolescent mothers $(<20$ years $)$ are more underweight than older mothers (20-49 years) in Afghanistan, attributing this to increased mother-child 
Table 1 Sample and nutritional status among adults in Afghanistan, 2018

\begin{tabular}{|c|c|c|c|c|c|c|}
\hline Variable (\#missing values) & $\begin{array}{l}\text { Sample } \\
\text { N (\%) }\end{array}$ & $\begin{array}{l}\text { Normal weight } \\
\mathrm{N}(\%)\end{array}$ & $\begin{array}{l}\text { Underweight } \\
\mathrm{N}(\%)\end{array}$ & $\begin{array}{l}\text { Overweight } \\
\mathrm{N}(\%)\end{array}$ & $\begin{array}{l}\text { Obesity } \\
\mathrm{N}(\%)\end{array}$ & $p$ value \\
\hline All & 3779 & $1774(49.5)$ & $264(7.8)$ & $1071(25.5)$ & $636(17.2)$ & \\
\hline \multicolumn{7}{|l|}{ Age in years (\#30) } \\
\hline $18-29$ & $1382(44.1)$ & $776(58.8)$ & $131(8.9)$ & $307(21.0)$ & $144(11.3)$ & \multirow[t]{3}{*}{$<0.001$} \\
\hline $30-44$ & $1124(32.2)$ & $460(42.7)$ & $69(7.4)$ & $352(27.1)$ & $239(22.8)$ & \\
\hline $45-69$ & $1243(23.8)$ & $525(41.8)$ & $62(6.2)$ & $402(31.6)$ & $252(20.4)$ & \\
\hline \multicolumn{7}{|l|}{ Sex $(\# 4)$} \\
\hline Female & $1753(44.1)$ & $723(42.1)$ & $156(9.1)$ & $465(25.1)$ & $389(23.7)$ & \multirow[t]{2}{*}{$<0.001$} \\
\hline Male & $2022(55.9)$ & $1051(55.3)$ & $108(6.7)$ & $606(25.9)$ & $247(12.1)$ & \\
\hline \multicolumn{7}{|l|}{ Education (\#3) } \\
\hline None & $2094(59.0)$ & $940(46.9)$ & $147(6.4)$ & $582(26.8)$ & $411(20.0)$ & \multirow[t]{3}{*}{0.133} \\
\hline Primary or less & $659(16.4)$ & $309(53.0)$ & $38(8.5)$ & $206(23.1)$ & $103(15.4)$ & \\
\hline Secondary or more & $1023(24.6)$ & $525(53.4)$ & $79(10.7)$ & $283(24.0)$ & $122(11.9)$ & \\
\hline \multicolumn{7}{|l|}{ Adult household members (\#3) } \\
\hline $1-3$ & $1352(23.9)$ & $616(50.5)$ & $102(7.2)$ & $402(28.7)$ & $215(13.7)$ & \multirow[t]{3}{*}{0.269} \\
\hline $3-5$ & $1229(34.3)$ & $606(49.9)$ & $90(8.9)$ & $347(25.6)$ & $178(15.6)$ & \\
\hline$\geq 6$ & $1195(41.8)$ & $552(48.6)$ & $72(7.1)$ & $322(23.7)$ & $243(20.6)$ & \\
\hline \multicolumn{7}{|l|}{ Residence (\#1) } \\
\hline Rural & $1797(42.4)$ & $922(51.9)$ & $140(8.3)$ & $471(25.1)$ & $249(14.7)$ & \multirow[t]{2}{*}{0.306} \\
\hline Urban & $1981(57.6)$ & $852(47.7)$ & $124(7.3)$ & $600(25.8)$ & $387(19.1)$ & \\
\hline \multicolumn{7}{|c|}{ Fruit and vegetable consumption (\#0) } \\
\hline$\leq 1$ servings & $2415(59.0)$ & $1164(50.3)$ & $182(8.7)$ & $650(25.3)$ & $401(15.7)$ & \multirow[t]{3}{*}{0.394} \\
\hline 2 servings & $883(29.6)$ & $389(47.9)$ & $51(6.8)$ & $285(27.8)$ & $149(17.5)$ & \\
\hline$\geq 3$ servings & $481(11.4)$ & $221(49.4)$ & $31(5.5)$ & $136(20.9)$ & $86(24.2)$ & \\
\hline \multicolumn{7}{|l|}{ For meal preparation (\#6) } \\
\hline Mainly butter or ghee & $2048(61.8)$ & $980(49.3)$ & $142(6.3)$ & $546(24.9)$ & $365(19.5)$ & \multirow[t]{2}{*}{0.022} \\
\hline Vegetable oil & $1725(38.2)$ & $793(49.9)$ & $122(10.1)$ & $523(26.3)$ & $271(13.7)$ & \\
\hline \multicolumn{7}{|l|}{ Add salt before/when eating (\#8) } \\
\hline Sometimes or rarely or never & $2697(68.4)$ & $1242(48.1)$ & $186(8.6)$ & $792(26.5)$ & $460(16.8)$ & \multirow[t]{2}{*}{0.226} \\
\hline Always or often & $1074(31.6)$ & $530(52.5)$ & $76(5.8)$ & $279(23.5)$ & $176(18.2)$ & \\
\hline \multicolumn{7}{|c|}{ Eats processed foods high in salt (\#27) } \\
\hline Sometimes or rarely or never & $3077(87.5)$ & $1424(49.5)$ & $216(7.8)$ & $893(25.6)$ & $524(17.0)$ & \multirow[t]{2}{*}{0.930} \\
\hline Always or often & $675(12.5)$ & $338(48.7)$ & $47(7.3)$ & $173(25.2)$ & $107(18.9)$ & \\
\hline \multicolumn{7}{|l|}{ Meals outside home (\#55) } \\
\hline 0 & $2477(65.9)$ & $1133(47.0)$ & $178(8.3)$ & $684(25.7)$ & $468(19.0)$ & \multirow[t]{2}{*}{0.374} \\
\hline$\geq 1$ & $1247(34.1)$ & $610(53.9)$ & $79(6.5)$ & $376(25.4)$ & $376(14.1)$ & \\
\hline \multicolumn{7}{|l|}{ Physical activity (\#35) } \\
\hline Low & $1384(38.4)$ & $591(41.5)$ & $94(7.6)$ & $377(27.1)$ & $303(23.8)$ & \multirow[t]{3}{*}{$<0.001$} \\
\hline Moderate & $624(18.3)$ & $267(50.9)$ & $46(7.3)$ & $202(24.4)$ & $106(17.4)$ & \\
\hline High & $1736(43.3)$ & $903(56.0)$ & $123(8.1)$ & $480(24.6)$ & $221(11.4)$ & \\
\hline \multicolumn{7}{|l|}{ Sedentary behaviour (\#24) } \\
\hline$<8 \mathrm{~h} /$ day & $2128(51.9)$ & $1037(54.5)$ & $144(6.6)$ & $580(23.9)$ & $346(15.1)$ & \multirow[t]{2}{*}{0.012} \\
\hline$\geq 8$ h/day & $1627(48.1)$ & $725(44.1)$ & $120(9.1)$ & $486(27.1)$ & 286 (19.6) & \\
\hline
\end{tabular}

Current tobacco use (\#3) 
Table 1 Sample and nutritional status among adults in Afghanistan, 2018 (Continued)

\begin{tabular}{|c|c|c|c|c|c|c|}
\hline Variable (\#missing values) & $\begin{array}{l}\text { Sample } \\
\text { N (\%) }\end{array}$ & $\begin{array}{l}\text { Normal weight } \\
\mathrm{N}(\%)\end{array}$ & $\begin{array}{l}\text { Underweight } \\
\mathrm{N}(\%)\end{array}$ & $\begin{array}{l}\text { Overweight } \\
\mathrm{N}(\%)\end{array}$ & $\begin{array}{l}\text { Obesity } \\
\mathrm{N}(\%)\end{array}$ & $p$ value \\
\hline No & $2910(72.0)$ & $1348(50.2)$ & $207(7.0)$ & $825(25.0)$ & $502(17.8)$ & 0.557 \\
\hline Yes & $866(28.0)$ & $426(47.7)$ & $57(9.6)$ & $246(26.9)$ & $134(15.8)$ & \\
\hline \multicolumn{7}{|l|}{ Ever alcohol use (\#3) } \\
\hline No & $3732(99.5)$ & $1751(49.4)$ & $261(7.8)$ & $1059(25.5)$ & $630(17.3)$ & 0.835 \\
\hline Yes & $44(0.5)$ & $23(58.9)$ & $3(8.4)$ & $12(21.5)$ & $6(11.2)$ & \\
\hline \multicolumn{7}{|l|}{ Hypertension (\#40) } \\
\hline No & $2566(69.3)$ & $1376(56.9)$ & $218(9.8)$ & $667(21.9)$ & $304(11.4)$ & $<0.001$ \\
\hline Yes & $1173(30.7)$ & $391(32.6)$ & $46(3.1)$ & $404(33.8)$ & $331(30.4)$ & \\
\hline \multicolumn{7}{|l|}{ Type 2 diabetes (\#292) } \\
\hline No & $3083(90.3)$ & $1500(52.2)$ & $211(7.7)$ & $870(25.1)$ & $480(14.9)$ & $<0.001$ \\
\hline Yes & $404(9.7)$ & $147(27.3)$ & $26(4.8)$ & $132(31.4)$ & $98(36.6)$ & \\
\hline \multicolumn{7}{|l|}{ Heart attack or stroke $(\# 3)$} \\
\hline No & 3488 (90.6) & $1658(49.6)$ & $250(7.9)$ & $978(25.5)$ & $571(17.1)$ & 0.933 \\
\hline Yes & $288(9.4)$ & $116(48.8)$ & $14(6.5)$ & $93(25.9)$ & 65 (18.7) & \\
\hline
\end{tabular}

nutritional demands. Some previous research showed an association between lower socioeconomic status and underweight $[18,35,36]$, but this study did not find this. One possible reason for this nonsignificant finding may be related to the measurement of economic status, which in this study was limited to the number of adult household members.

In bivariate analysis, obesity was higher in women (23.7\%) compared to men (12.1\%), which is in line with previous studies [12, 35, 36]. Consistent with previous research $[14,35,36]$, overweight/obesity increased with age. While some previous studies [12, 35-37] found an association between higher economic status (less household crowding), education, and residing in urban areas and having overweight/obesity, this survey did not show significant associations. Similar results of a nonassociation between education, income, and job categories with overweight/obesity in adults in Kabul [14]. It is possible that educational level did not impact on body weight status because of the high proportion of the study population (59.0\%) not having a formal education. Of concern is as well that $32.3 \%$ of young people aged 1829 years were already overweight or obese, showing that a large proportion of overweight/obesity is already established in early adulthood. Therefore, obesity interventions starting in childhood or adolescents should be prioritized in Afghanistan [38].

In terms of dietary behaviour, previous research found associations between inadequate fruit and vegetable intake [39, 40], eating occasions away from home [41], high salt intake [42], consumption of processed foods and saturated fat [43], and obesity, while this study did not find significant associations between dietary behaviour (inadequate fruit and vegetable intake, having meals outside home, high salt intake, high intake of processed foods, and intake of saturated fats) and underweight as well as overweight or obesity. This study lacked to assess other dietary behaviours, such as frequent snacking, skipping breakfast, and high intake of sugary beverages, which may have been responsible for a higher rate of overweight/obesity $[3,44]$.

In agreement with previous studies [37-39, 45, 46], this study showed that physical activity was inversely and high sedentary behaviour was in bivariate analysis positively associated with overweight/obesity. Unlike some previous research [12, 38, 45], this study showed no (negative) association between current tobacco use and the prevalence of overweight/obesity. Consistent with previous research in Laos [33], this study found that current tobacco use increased and having hypertension decreased the odds of having underweight. As shown previously for hypertension $[10,12]$ and diabetes $[10,12,38]$, we found an association between NCDs (hypertension and diabetes) and overweight/obesity. This result emphasizes the fact that adults in Afghanistan suffer from several NCD risk factors at the same time [13], calling for multiple risk factor interventions $[12,14]$.

\section{Study limitations}

Apart from physical and biomedical measures selfreported questionnaire data may have suffered from biased responses. Another limitation was the crosssectional nature of the survey, which does not allow for causative conclusions. Some variables, such as more details on dietary behaviour, should be included in future studies. 
Table 2 Multivariable associations with underweight and overweight/obesity (with normal weight as reference category)

\begin{tabular}{|c|c|c|c|c|}
\hline \multirow[t]{2}{*}{ Variable } & \multicolumn{2}{|l|}{ Underweight } & \multicolumn{2}{|l|}{ Overweight/Obesity } \\
\hline & Adjusted RRR (95\% Cl) & $p$ value & Adjusted RRR (95\% Cl) & $p$ value \\
\hline \multicolumn{5}{|l|}{ Age in years } \\
\hline $18-29$ & 1 (Reference) & & 1 (Reference) & \\
\hline $30-44$ & $0.90(0.55,1.77)$ & 0.972 & $2.00(1.51,2.66)$ & $<0.001$ \\
\hline $45-69$ & $0.91(0.45,1.87)$ & 0.805 & $1.58(1.09,2.31)$ & 0.017 \\
\hline \multicolumn{5}{|l|}{ Sex } \\
\hline Female & 1 (Reference) & & 1 (Reference) & \\
\hline Male & $0.30(0.15,0.58)$ & $<0.001$ & $0.74(0.47,1.17)$ & 0.201 \\
\hline \multicolumn{5}{|l|}{ Education } \\
\hline None & 1 (Reference) & & 1 (Reference) & \\
\hline Primary or less & $2.01(0.67,6.02)$ & 0.210 & $0.88(0.58,1.32)$ & 0.528 \\
\hline Secondary or more & $2.75(0.98,7.71)$ & 0.054 & $1.06(0.65,1.74)$ & 0.809 \\
\hline \multicolumn{5}{|l|}{ Adult household members } \\
\hline $1-3$ & 1 (Reference) & & 1 (Reference) & \\
\hline $3-5$ & $1.22(0.66,2.26)$ & 0.533 & $0.82(0.55,1.20)$ & 0.299 \\
\hline$\geq 6$ & $0.96(0.52,1.80)$ & 0.908 & $0.93(0.69,1.31)$ & 0.689 \\
\hline \multicolumn{5}{|l|}{ Residence } \\
\hline Rural & 1 (Reference) & & 1 (Reference) & \\
\hline Urban & $0.70(0.42,1.15)$ & 0.156 & $1.05(0.79,1.40)$ & 0.733 \\
\hline \multicolumn{5}{|l|}{ Fruit and vegetable consumption } \\
\hline$\leq 1$ servings & 1 (Reference) & & 1 (Reference) & \\
\hline 2 servings & $0.85(0.49,1.46)$ & 0.548 & $1.11(0.69,1.79)$ & 0.670 \\
\hline$\geq 3$ servings & $0.36(0.09,1.50)$ & 0.159 & $1.26(0.84,1.90)$ & 0.264 \\
\hline \multicolumn{5}{|l|}{ For meal preparation } \\
\hline Mainly butter or ghee & 1 (Reference) & & 1 (Reference) & \\
\hline Vegetable oil & $1.65(0.82,3.31)$ & 0.157 & $0.99(0.78,1.27)$ & 0.967 \\
\hline \multicolumn{5}{|l|}{ Add salt before/when eating } \\
\hline Sometimes or rarely or never & 1 (Reference) & & 1 (Reference) & \\
\hline Always or often & $0.48(0.28,1.03)$ & 0.062 & $0.91(0.64,1.29)$ & 0.590 \\
\hline \multicolumn{5}{|l|}{ Eats processed foods high in salt } \\
\hline Sometimes or rarely or never & 1 (Reference) & & 1 (Reference) & \\
\hline Always or often & $0.85(0.44,1.64)$ & 0.620 & $1.36(0.74,2.50)$ & 0.315 \\
\hline \multicolumn{5}{|l|}{ Meals outside home } \\
\hline 0 & 1 (Reference) & & 1 (Reference) & \\
\hline$\geq 1$ & $0.73(0.20,2.64)$ & 0.624 & $1.03(0.57,1.87)$ & 0.923 \\
\hline \multicolumn{5}{|l|}{ Physical activity } \\
\hline Low & 1 (Reference) & & 1 (Reference) & \\
\hline Moderate & $0.72(0.32,1.64)$ & 0.434 & $0.75(0.51,1.10)$ & 0.143 \\
\hline High & $0.77(0.43,1.38)$ & 0.371 & $0.70(0.50,0.98)$ & 0.037 \\
\hline \multicolumn{5}{|l|}{ Sedentary behaviour } \\
\hline$<8$ h/day & 1 (Reference) & & 1 (Reference) & \\
\hline$\geq 8$ h/day & $1.85(1.11,3.10)$ & 0.019 & $1.24(0.95,1.63)$ & 0.112 \\
\hline \multicolumn{5}{|l|}{ Current tobacco use } \\
\hline No & 1 (Reference) & & 1 (Reference) & \\
\hline
\end{tabular}


Table 2 Multivariable associations with underweight and overweight/obesity (with normal weight as reference category) (Continued)

\begin{tabular}{|c|c|c|c|c|}
\hline \multirow[t]{2}{*}{ Variable } & \multicolumn{2}{|l|}{ Underweight } & \multicolumn{2}{|l|}{ Overweight/Obesity } \\
\hline & Adjusted RRR (95\% Cl) & $p$ value & Adjusted RRR (95\% CI) & $p$ value \\
\hline Yes & $2.58(1.08,6.16)$ & 0.033 & $1.13(0.83,1.55)$ & 0.439 \\
\hline \multicolumn{5}{|c|}{ Ever alcohol use } \\
\hline No & 1 (Reference) & & 1 (Reference) & \\
\hline Yes & $0.73(0.08,6.79)$ & 0.783 & $0.41(0.08,2.08)$ & 0.279 \\
\hline \multicolumn{5}{|c|}{ Hypertension } \\
\hline No & 1 (Reference) & & 1 (Reference) & \\
\hline Yes & $0.51(0.27,0.95)$ & 0.034 & $2.74(1.89,3.96)$ & $<0.001$ \\
\hline \multicolumn{5}{|c|}{ Type 2 diabetes } \\
\hline No & 1 (Reference) & & 1 (Reference) & \\
\hline Yes & $1.17(0.53,2.52)$ & 0.704 & $1.82(1.13,2.94)$ & 0.014 \\
\hline
\end{tabular}

$R R R$ relative risk ratio, $\mathrm{Cl}$ confidence interval

\section{Conclusion}

The study found in the 2018 adult national Afghanistan STEPS survey that almost one in ten adult participants were underweight and more than two in five were overweight/obese. Several factors associated with body weight status, including female sex, current tobacco use and sedentary behaviour for underweight and older age, hypertension, type 2 diabetes, and physical inactivity for overweight/obesity, were identified. Increased public health interventions are needed to address both forms of malnutrition (underweight and overweight/obesity) and associated factors to improve the health of Afghans.

\section{Acknowledgements}

"The data source, the World Health Organization NCD Microdata Repository (URL: https://extranet.who.int/ncdsmicrodata/index.php/catalog), is hereby acknowledged."

\section{Authors' contributions}

"All authors fulfil the criteria for authorship. SP and KP conceived and designed the research, performed statistical analysis, drafted the manuscript, and made critical revisions of the manuscript for key intellectual content. All authors read and approved the final version of the manuscript and have agreed to the authorship and order of authorship for this manuscript."

\section{Funding}

The analysis received no funding.

\section{Availability of data and materials}

"The data for the current study are publicly available at the World Health Organization NCD Microdata Repository (URL: https://extranet.who.int/ ncdsmicrodata/index.php/catalog)."

\section{Declarations}

All methods were carried out in accordance with relevant guidelines and regulations.

\section{Ethics approval and consent to participate}

The study was approved by the Ministry of Public Health Ethics Board, and written informed consent was obtained from participants [20].

\section{Consent for publication}

Not applicable

\section{Competing interests}

The authors declare that they have no competing interests.

\section{Author details}

${ }^{1}$ ASEAN Institute for Health Development, Mahidol University, Salaya, Phutthamonthon, Nakhon Pathom, Thailand. '2Department of Research Administration and Development, University of Limpopo, Turfloop, Mankweng, South Africa. ${ }^{3}$ Department of Psychology, University of the Free State, Bloemfontein, South Africa. ${ }^{4}$ Department of Psychology, College of Medical and Health Science, Asia University, Taichung, Taiwan.

Received: 25 March 2021 Accepted: 27 May 2021

Published online: 06 June 2021

\section{References}

1. NCD Risk Factor Collaboration (NCD-RisC). Trends in adult body mass index in 200 countries from 1975 to 2014: a pooled analysis of 1698 populationbased measurement studies with 19.2 million participants. Lancet. 2016; 387(10026):1377-96. https://doi.org/10.1016/S0140-6736(16)30054-X.

2. Nasreddine L, Ayoub JJ, Al JA. Review of the nutrition situation in the eastern Mediterranean region. East Mediterr Health J. 2018;24(1):77-91. https://doi.org/10.26719/2018.24.1.77.

3. Musaiger $\mathrm{AO}$. Overweight and obesity in eastern mediterranean region: prevalence and possible causes. J Obes. 2011;2011:407237-17. https://doi. org/10.1155/2011/407237.

4. Janghorbani M, Amini M, Willett WC, Mehdi Gouya M, Delavari A, Alikhani S, et al. First nationwide survey of prevalence of overweight, underweight, and abdominal obesity in Iranian adults. Obesity. 2007;15(11):2797-808. https://doi.org/10.1038/oby.2007.332.

5. Pengpid S, Peltzer K. Overweight and obesity among adults in Iraq: prevalence and correlates from a National Survey in 2015. Int J Environ Res Public Health. 2021;18(8):4198. https://doi.org/10.3390/ijerph18084198.

6. Ajlouni K, Khader Y, Batieha A, Jaddou H, El-Khateeb M. An alarmingly high and increasing prevalence of obesity in Jordan. Epidemiol Health. 2020;42: e2020040. https://doi.org/10.4178/epih.e2020040.

7. Pengpid S, Peltzer K. Prevalence and correlates of the metabolic syndrome in a cross-sectional community-based sample of 18-100 year-olds in Morocco: results of the first national STEPS survey in 2017. Diabetes Metab Syndr. 2020;14(5):1487-93. https://doi.org/10.1016/j.dsx.2020.07.047.

8. Abdeen Z, Jildeh C, Dkeideek S, Qasrawi R, Ghannam I, Al SH. Overweight and obesity among Palestinian adults: analyses of the anthropometric data from the first National Health and nutrition survey (1999-2000). J Obes. 2012;2012:213547-12. https://doi.org/10.1155/2012/213547.

9. World Factbook. Afghanistan. URL: https://www.cia.gov/library/publications/ the-world-factbook/geos/af.html (accessed 25 Jan 2021).

10. Saeed KMI. Prevalence of risk factors for non-communicable diseases in the adult population of urban areas in Kabul City, Afghanistan. Cent Asian J Glob Health. 2014;2(2):69. https://doi.org/10.5195/cajgh.2013.69. 
11. Saeed KM. Burden of hypertension in the Capital of Afghanistan: a crosssectional study in Kabul City, 2015. Int J Hypertens. 2017;2017:3483872-7. https://doi.org/10.1155/2017/3483872.

12. Saeed KM. Prevalence and associated risk factors for obesity in Jalalabad city - Afghanistan. Alexandria J Med. 2015;51(4):347-52. https://doi.org/10.1016/ j.ajme.2014.12.004

13. Saeed KM, Rasooly MH, Alkozai A. Prevalence of risk factors for noncommunicable diseases in Jalalabad city, Afghanistan, evaluated using the WHO STEPwise approach. East Mediterr Health J. 2016;21(11):783-90.

14. Saeed KMI, Rasooly MH, Nejaby M. Profile of risk factors for noncommunicable diseases in major cities of Afghanistan: WHO STEPwise approach. East Mediterr Health J. 2020;26(4):388-99. https://doi.org/10.2671 9/emhj.20.005

15. Akseer N, Bhatti Z, Mashal T, Soofi S, Moineddin R, Black RE, et al. Geospatial inequalities and determinants of nutritional status among women and children in Afghanistan: an observational study. Lancet Glob Health. 2018; 6(4):e447-59. https://doi.org/10.1016/S2214-109X(18)30025-1.

16. Nubé M, Van Den Boom GJ. Gender and adult undernutrition in developing countries. Ann Hum Biol. 2003;30(5):520-37. https://doi.org/10.1080/030144 6031000119601.

17. Pi-Sunyer X. The medical risks of obesity. Postgrad Med. 2009;121(6):21-33. https://doi.org/10.3810/pgm.2009.11.2074.

18. Pengpid S, Peltzer K. The prevalence and associated factors of underweight and overweight/obesity among adults in Kenya: evidence from a national cross-sectional community survey. Pan Afr Med J. 2020;36:338. https://doi. org/10.11604/pamj.2020.36.338.21215.

19. World Health Organization (WHO) STEPwise approach to surveillance (STEP S), 2018. URL: https://www.who.int/ncds/surveillance/steps/en/ (accessed 25 Jan 2021)

20. JS Consultancy Services, Non-Communicable Disease Risk Factor Survey Country Report for Afghanistan. URL: https://extranet.who.int/ncdsmicroda ta/index.php/catalog/782 (accessed 25 Jan 2021)

21. World Health Organization (WHO)- Europe. Body Mass Index https://www euro.who.int/en/health-topics/disease-prevention/nutrition/a-healthylifestyle/body-mass-index-bmi (accessed 25 Jan 2021).

22. Chobanian AV, Bakris GL, Black HR, Cushman WC, Green LA, Izzo JL Jr, et al. Seventh report of the joint National Committee on prevention, detection, evaluation, and treatment of high blood pressure. Hypertension. 2003;42(6): 1206-52. https://doi.org/10.1161/01.HYP.0000107251.49515.c2.

23. NCD Risk Factor Collaboration (NCD-RisC). Worldwide trends in diabetes since 1980: a pooled analysis of 751 population-based studies with 4.4 million participants. Lancet. 2016;387(10027):1513-30 https://doi.org/10.101 6/S0140-6736(16)00618-8

24. Ekelund U, Steene-Johannessen J, Brown WJ, Fagerland MW, Owen N, Powell KE, et al. Does physical activity attenuate, or even eliminate, the detrimental association of sitting time with mortality? A harmonised metaanalysis of data from more than 1 million men and women. Lancet. 2016; 388(10051):1302-10. https://doi.org/10.1016/S0140-6736(16)30370-1.

25. Armstrong T, Bull F. Development of theWorld health organization global physical activity questionnaire (GPAQ). J Public Health. 2006;14(2):66-70. https://doi.org/10.1007/s10389-006-0024-x.

26. Melki IS, Beydoun HA, Khogali M, Tamim H. Yunis KA; National Collaborative Perinatal Neonatal Network (NCPNN). Household crowding index: a correlate of socioeconomic status and inter-pregnancy spacing in an urban setting. J Epidemiol Community Health. 2004;58(6):476-80. https://doi.org/1 0.1136/jech.2003.012690.

27. Djalalinia S, Saeedi Moghaddam S, Sheidaei A, Rezaei N, Naghibi Iravani SS, Modirian M, et al. Patterns of obesity and overweight in the Iranian population: findings of STEPs 2016. Front Endocrinol. 2020;11:42. https://doi. org/10.3389/fendo.2020.00042.

28. Peng W, Mu Y, Hu Y, Li B, Raman J, Sui Z. Double burden of malnutrition in the Asia-Pacific region-a systematic review and meta-analysis. J Epidemiol Glob Health. 2020;10(1):16-27. https://doi.org/10.2991/jegh.k.191117.002.

29. Popkin BM. An overview on the nutrition transition and its health implications: the Bellagio meeting. Public Health Nutr. 2002;5(1A):93-103. https://doi.org/10.1079/phn2001280.

30. Haddad L, Cameron L, Barnett I. The double burden of malnutrition in SE Asia and the Pacific: priorities, policies and politics. Health Policy Plan. 2015; 30(9):1193-206. https://doi.org/10.1093/heapol/czu110.

31. Hanandita W, Tampubolon G (2015) The double burden of malnutrition in Indonesia: social determinants and geographical variations. SMM-
Population Health 1: 16-25. doi: https://doi.org/10.1016/j.ssmph.2015.10.002. eCollection 2015 Dec.

32. Letamo G, Navaneetham K. Prevalence and determinants of adult undernutrition in Botswana. PLoS One. 2014;9(7):e102675. https://doi.org/10.1371/ journal.pone.0102675 eCollection 2014.

33. Pengpid S, Vonglokham M, Kounnavong S, Sychareun V, Peltzer K. The prevalence of underweight and overweight/obesity and its correlates among adults in Laos: a cross-sectional national population-based survey, 2013. Eat Weight Disord. 2020;25(2):265-73. https://doi.org/10.1007/s40519018-0571-5.

34. Jaacks $L M$, Slining MM, Popkin BM. Recent trends in the prevalence of under- and overweight among adolescent girls in low- and middle-income countries. Pediatr Obes. 2015;10(6):428-35. https://doi.org/10.1111/ijpo.12 000.

35. Biswas T, Garnett SP, Pervin S, Rawal LB. The prevalence of underweight, overweight and obesity in Bangladeshi adults: data from a national survey. PLoS One. 2017;12(5):e0177395. https://doi.org/10.1371/journal.pone.01773 95 eCollection 2017.

36. Pengpid S, Peltzer K. The prevalence of underweight, overweight and obesity and their related lifestyle factors in Indonesia, 2014-15. AIMS Public Health. 2017;4(6):633-49. https://doi.org/10.3934/publichealth.2017.6.633.

37. Mkuu RS, Epnere K, Chowdhury MAB. Prevalence and predictors of overweight and obesity among Kenyan women. Prev Chronic Dis. 2018;15: E44. https://doi.org/10.5888/pcd15.170401.

38. Weiderpass E, Botteri E, Longenecker JC, Alkandari A, Al-Wotayan R, Al Duwairi Q, et al. The prevalence of overweight and obesity in an adult Kuwaiti population in 2014. Front Endocrinol. 2019;10:449. https://doi.org/1 0.3389/fendo.2019.00449

39. Pengpid S, Peltzer K. Associations between behavioural risk factors and overweight and obesity among adults in population-based samples from 31 countries. Obes Res Clin Pract. 2017;11(2):158-66. https://doi.org/10.1016/j. orcp.2016.08.001.

40. Carnauba RA, Chaves DF, Baptistella AB, Paschoal V, Naves A, Buehler AM. Association between high consumption of phytochemical-rich foods and anthropometric measures: a systematic review. Int J Food Sci Nutr. 2017; 68(2):158-66. https://doi.org/10.1080/09637486.2016.1229761.

41. Affenito SG, Franko DL, Striegel-Moore RH, Thompson D. Behavioral determinants of obesity: research findings and policy implications. J Obes. 2012;2012:150732-4. https://doi.org/10.1155/2012/150732.

42. Allison SJ. Metabolism: high salt intake as a driver of obesity. Nat Rev Nephrol. 2018;14(5):285. https://doi.org/10.1038/nrneph.2018.23.

43. Askari M, Heshmati J, Shahinfar H, Tripathi N, Daneshzad E. Ultra-processed food and the risk of overweight and obesity: a systematic review and metaanalysis of observational studies. Int J Obes. 2020;44(10):2080-91. https://doi. org/10.1038/s41366-020-00650-z.

44. Al-Tawil NG, Abdulla MM, Abdul Ameer AJ. Prevalence of and factors associated with overweight and obesity among a group of Iraqi women. East Mediterr Health J. 2007;13(2):420-9.

45. Shabu S. Prevalence of overweight/obesity and associated factors in adults in Erbil, Iraq: a household survey. Zanco J Med Sci. 2019;23(1):128-134. https://doi.org/https://doi.org/10.15218/zjms.2019.017.

46. World Health Organization (WHO). Obesity and overweight fact sheet, 2011. Department of Sustainable Development and Healthy Environments. URL: http://www.searo.who.int/entity/noncommunicable_diseases/media/non_ communicable_diseases_obesity_fs.pdf (accessed 10 June 2020).

\section{Publisher's Note}

Springer Nature remains neutral with regard to jurisdictional claims in published maps and institutional affiliations. 